\title{
Research Note \\ Social Trends and Ecotourism: Adventure Recreation and Amenity Migration
}

\author{
Ralf Buckley \\ International Centre for Ecotourism Research, Griffith University, Qld, \\ Australia
}

\section{Introduction}

Ecotourism is a convenient term for a particular class of human behaviours, real as well as idealised. One critical component of ecotourism research is hence the continual re-examination of what tourists and tourism providers actually do in regard to the defining criteria of ecotourism. And since in practice, people rarely divide their lifestyles into neat packages, social trends outside the ecotourism sector itself maybe as significant as those within it. Whilst the largest-scale megatrends (Buckley, 1998) have not changed significantly over the past decade, there are two medium-scale social trends in developed nations which seem likely to exert strong influences on the development of ecotourism during the next decade.

\section{Adventure Tourism}

The first to these is the growth in adventure tourism and the associated commercialisation of outdoor recreation and outdoor education. This includes both growth in volume, largely at the low-skill soft end of the adventure tourism spectrum; and growth in geographic coverage and the range of products offered, largely at the high-skill hard end of the spectrum (Buckley, 2004b). As increasing numbers of people want to visit remote rural or wilderness areas not only to observe nature and culture, but to engage in a variety of extreme sports, local impacts and expectations of tourism shift accordingly. Of course, ecotourism has only become a recognised construct over recent decades. Expeditions to remote areas, e.g. for hunting or exploration, have a much longer history.

Two aspects are new. The first is the increasing commercialisation of expeditions as packaged tourism products. Guided ascents of Mount Everest provide a particularly well-known example. The second new aspect is the increasing incorporation of outdoor sports in such commercial expeditions. Examples range from base-jumping on Baffin Island to surfing the remote reefs of the South Pacific. One of the defining features for many of these new products is that they are available or attractive only to clients who, nominally at least, already possess a high level of skill in the relevant outdoor sport. Formal qualifications may also be required, as for example in scuba diving. As a general descriptor, therefore, these products may be referred to as 
skilled commercial adventure recreation in remote areas, SCARRA (Buckley, $2004 b$ ). In practice, one of the major management issues for SCARRA operators is that clients often overstate or overestimate their skills. Service providers, and individual guides, face difficult decisions and ethical issues in balancing customer satisfaction with customer safety (Fennell, 2002).

The boundaries between nature, eco and adventure tourism have become increasingly blurred over recent years (Buckley, 2000). Some SCARRA products use the natural environment purely as an adventure playground. Such products typically have high environmental impacts, no attempt at environmental education, and no contribution to conservation. Other products, however, do indeed have environmental management programmes in place, and may contribute to conservation either through mandatory park use fees, or by providing economic and social incentives to conserve areas for commercial recreation rather than allocating them for primary production. Educational components are less common, but not unknown.

\section{Case Studies}

The environmental impacts of some adventure tours, such as rubbish and oxygen bottles left by both private and commercial expeditions on Mount Everest, have received widespread publicity. Indeed, expeditions have subsequently been run specifically to clean up this litter (Buckley, 2003a). Some expeditions have also attempted to fulfil a role in public environmental education, through radio broadcasts and Web logs transmitted by satellite phone. A recent expedition on the Himalayan Mountain K2, for example, made a live broadcast to the Tourism Dialogue of the Barcelona Forum on 15 July 2004, with a strong environmental message. Whether such broadcasts lead listeners to change their lifestyles so as to reduce their personal ecological footprints, or whether the broadcasts serve merely to publicise tourism opportunities, apparently remains untested.

Similar considerations also applies for soft adventure in remote areas, such as boat cruises to the Antarctic. Such cruises can produce a range of environmental impacts, notably on nesting seabirds (Buckley, 2003a, 2004a). Some tour operators certainly take steps to minimise boat-based pollution and to manage passenger interactions with wildlife; and they argue that taking tourists to the Antarctic creates a constituency to support Antarctic conservation. As noted by Bauer (1997), however, there appears to be no hard evidence that Antarctic nature tourists subsequently see themselves as environmental lobbyists.

In other remote areas such as the High Arctic, adventure and eco tour operators face additional complications in the shape of local indigenous populations with a mixed cash and subsistence hunting and fishing lifestyle. For example, several companies now run seakayaking tours in the High Arctic, where one of the major attractions is the opportunity to see rare marine mammals such as narwhal. These tours may use boats owned by local Inuit, often purchased through government grants or funding schemes, to shuttle people and equipment. The Inuit people themselves, however, use the same boats to hunt narwhal with modern medium-calibre rifles 
(Buckley, personal observation, 2003). Indeed, having dropped off seakayaks and kayakers they may go directly to hunt the same narwhal which the kayakers hope to watch, on the same trip. From the Inuit perspective this is efficient, since the kayakers have already paid fuel costs for the trip. From the perspective of tour operators and clients, however, it presents ethical dilemmas as well as reducing opportunities to watch narwhal. The narwhal tusks, apparently, are generally sold to passengers on cruise ships from countries which are not signatories to the Convention on International Trade in Endangered Species. Thus on the one hand these seakayak tours may help teach clients about Arctic environments and biodiversity, including narwhal; whilst on the other they may contribute, or at least be complicit, in commercial trophy hunting of the same species.

Whilst High Arctic seakayak tours are certainly adventurous, therefore, whether or not they may be considered as ecotourism raises much broader issues, such as: conflicts between environmental conservation and the rights and cultures of indigenous peoples; whether or not hunting for sale of trophies should be distinguished from hunting for subsistence consumption, especially if the hunters are not dependent on subsistence lifestyles; and whether or not indigenous peoples should be accorded special rights for hunting, especially if they hunt with modern rather than traditional weapons and transport, and especially if these have been subsidised by the taxpayer.

Even in developed nations with relatively well-funded research institutions, government agencies and industry associations, accurate scientific data on environmental impacts of outdoor recreation and adventure tourism are rather limited (Buckley, 2004a). For adventure tours in remote areas, relevant data are event more fragmentary. Remote pristine environments, however, may be highly vulnerable to even very low levels of human visitation, particularly if visitors are engaged in outdoor sporting activities at the limits of their capabilities, and may have neither knowledge nor opportunity to avoid or minimise impacts. Whilst both the likelihood and magnitude of most types of impacts do increase with visitor numbers, even a single visitor can inadvertently introduce weed seeds, insect pests, or fungal spores and other pathogens, whether on vehicles, boats, camping gear or sporting equipment, or clothing and footwear. In addition, many birds and other wildlife species are subject to intense pressure from predators during breeding periods, and even a single human disturbance can cause catastrophic breeding failure for entire colonies (Buckley, 2004a).

\section{Amenity Migration}

Increasing interest in outdoor recreation is closely coupled with a second major social trend, namely amenity migration. Having first found their favourite holiday areas, many city dwellers then move there. Their reasons are varied (Stewart, 2001), but may typically include: a quality-of-life choice of lifestyle over gross income; the opportunity to continue high-paying jobs and businesses quite effectively from rural areas for as long as they have good internet connections, couriers and airports; lower property prices; and increasingly, job opportunities in the so-called second-tier tourism economy, providing retail 
goods and services to tourists and to other amenity migrants. Certainly, communications technologies have been a key enabling factor in large-scale amenity migration, since highly-paid professionals no longer need to live in metropolitan areas. But it is outdoor and adventure recreation opportunities that provide the main attraction. The historical tradition of amenity migration in Europe was for wealthy older residents to retire from cold northern cities to warmer southern beaches. The main amenity migration trend in North America over recent decades, however, has been for active younger entrepreneurs to move to mountainous areas such as the Sierras and the Rockies (Buckley, 2003a; Johnson et al., 2003; Lichtman, 2001; Moss, 2003).

The impacts on rural infrastructure and property prices have in many cases been considerable, and conflicts can occur between new migrants and long-term residents over issues such as land access, conservation, schooling, fire control, local government rates and so on. Long-term residents who are prepared to sell land and retire can reap windfall profits, but those who remain dependent on local farm incomes may face difficulties from higher costs and taxes.

Amenity migration may also produce a range of impacts on the natural environment (Buckley, 2003b; Lichtman, 2001). Areas of forest or other relatively undisturbed native ecosystems may be fragmented through subdivision, fencing, access roads, electricity cabling, and clearance for house and garden sites. Encroachment of fenced residential areas around national parks may restrict the movement of wildlife. Household pets become predators on native birds, reptiles and small mammals, and may escape to add to feral populations within protected areas. Fire regimes and fire management options are changed. Consumption of freshwater increases, and so does production of sewage, with associated water pollution. Road traffic also increases, with associated noise disturbance and roadkill.

The environmental impacts of amenity migration are not always negative, however. Depending on the prior land-use and the motivations of migrants, new residents may make a significant private contribution to conservation. This can occur particularly in areas where market factors or government policies are leading farmers or forestry operations to expand into marginal areas which were not economically viable in the past, and which historically provided buffer zones around protected areas. In such circumstances, where new immigrants have independent income streams with no incentive to continue clearance, amenity migration can put a halt, or at least a damper, on environmentally destructive primary production practices. Indeed, where new migrants have personal interests in conservation, or where they rely on undisturbed scenery either for personal amenity, to maintain property values, or to underpin new tourism businesses, such effects may be stronger still.

\section{Discussion and Conclusions}

In their more extreme manifestations, amenity migration and adventure recreation are clearly very different. The gated residential communities west of Waterton and Glacier National Parks on the US-Canada border, for example, with their exclusive golf courses and private security firms, are a 
far cry from a commercial mountain climb, helisafari or river-rafting trip in the Himalayas. Both of these two large-scale social trends, however, seem to be driven by the same factor, namely an increasing demand for outdoor recreation. For many people, amenity migration is a simply an extension or progression of a long-held interest in adventure recreation. Thus there are strong links or indeed overlaps between the two trends, with tourism in a central role (Johnson et al., 2003a). Equally, the environmental costs and benefits of lowfrequency adventure tourism in remote areas may merge imperceptibly into those of amenity migration in heavily-frequented areas. The limitations of research to date in recreational ecology (Buckley, 2004a) thus become critical not only for protected area management, but also for conservation or otherwise on adjacent private lands.

Equally, the limitations of environmental economics research on values, benefits, costs and mechanisms for biodiversity, ecosystem, health and recreational services associated with protected areas are also significant for other public and private lands of high conservation value. Policy mechanisms and incentive schemes designed to promote conservation practices on production agricultural properties, such as the Countryside Conservation Scheme in the UK (UKDEFRA, 2004) now overlap with those aimed primarily at conservation-conscious landholders such as many amenity migrants (e.g. NSWNPWS, 2004). Both of these provide new opportunities for crossfertilisation between research disciplines, and between research and policy design.

\section{Acknowledgements}

Components of this research note were presented previously at two symposia in The Barcelona Forum, July 2004.

\section{Correspondence}

Any correspondence should be directed to Ralf Buckley, International Center for Ecotourism Research, Griffith University, Parklands Drive, Southport, Qld 4215, Australia (R.Buckley@griffith.edu.au).

\section{References}

Bauer, T. (1997) Commercial tourism in the Antarctic: Trends, opportunities, constraints and regulation. PhD thesis, Monash University, Melbourne.

Buckley, R.C. (1998) Ecotourism megatrends. Australian International Business Review 1998, 52-54.

Buckley, R.C. (2000) NEAT trends: current issues in nature, eco and adventure tourism. International Journal of Tourism Research 2, 437-444.

Buckley, R.C. (2003a) Sustainability issues in mountain tourism. In L. Taylor and A. Ryall (eds) Sustainable Mountain Communities (pp. 169-174). The Banff Centre, Banff.

Buckley, R.C. (2003b) The practice and politics of tourism and land management. In R.C. Buckley, C. Pickering and D. Weaver (eds) Nature-Based Tourism, Environment and Land Management (pp. 1-6). Oxford: CAB International.

Buckley, R.C. (ed) (2004a) Environmental Impacts of Ecotourism. Oxford: CAB International.

Buckley, R.C. (2004b) Commercial adventure recreation in remote areas: the edge of tourism. In T.V. Singh (ed.) New Horizons in Tourism (pp. 37-48). Oxford: CAB International. 
Fennell, D. (2002) Ecotourism Programme Planning. Oxford: CAB International.

Johnson, J., Maxwell, B. and Aspinall, R. (2003) Moving nearer to heaven: Growth and change in the Greater Yellowstone Region, USA. In R.C. Buckley, C. Pickering and D. Weaver (eds) Nature-Based Tourism, Environment and Land Management (pp. 77-88). Oxford: CAB International.

Lichtman, P. (2001) Amenity migrants and their impacts. In L. Taylor and A. Ryall (eds) Sustainable Mountain Communities (pp. 73-75). Banff: The Banff Centre.

Moss, L.A.G. (2003) Amenity migration: Global phenomenon and strategic paradigm for sustaining mountain environmental quality. In L. Taylor and A. Ryall (eds) Sustainable Mountain Communities (pp. 19-24). Banff: The Banff Centre.

New South Wales National Parks and Wildlife Service (2004) Voluntary Conservation Agreements. On WWW at http://www.nationalparks.nsw.gov.au/npws.nsf/ Content/Voluntary + conservation + agreement. Accessed 3.8.04.

Stewart, S.I. (2001) Amenity migration. In K. Luft and S. McDonald (eds) Trends 2000: Shaping the Future (pp. 369-378). Proceedings of the 5 Outdoor Recreation and Tourism Trends. September 2000. Department of Park, Recreation, and Tourism Resources, Lansing, MI.

UKDEFRA (2004) Countryside Stewardship Scheme. On WWW at http://www.defra. gov.uk/erdp/schemes/css/default.htm. Accessed 3.8.04. 